\title{
Short-term effects of canopy and surface fire on centipede (Chilopoda) communities in a semi natural Mediterranean forest
}

\author{
Emiliano Trucchi, Monica Pitzalis, Marzio Zapparoli \& Marco A. Bologna
}

\begin{abstract}
Trucchi, E., Pitzalis, M., Zapparoli, M. \& Bologna, M. A. 2009: Short-term effects of canopy and surface fire on centipede (Chilopoda) communities in a semi natural Mediterranean forest. — Entomol. Fennica 20: 129-138.
\end{abstract}

Species composition and structure of centipede (Chilopoda) communities were studied in a sub-urban burnt forest on the Mediterranean coast near Roma, Italy. The study was carried out in two sites affected by canopy fire (complete vegetation destruction), one affected by surface fire (persistence of tree canopy), and three unburnt sites. Monthly, quantitative/qualitative samplings were performed in each site from April 2001 to April 2002 by pitfall trapping and one hour active search. Analyses of species composition, dominance structure, diversity and colonization progress were performed. Centipede communities of the sites affected by canopy fire were simply structured, poor in both species richness and diversity; conversely, species composition, structure and diversity of the community affected by surface fire were scarcely modified.

E. Trucchi, Dipartimento di Biologia, Università degli Studi Roma Tre, Viale Marconi 446, 00146 Roma, Italy; Present address: Dipartimento di Biologia, Università Roma Tor Vergata, Via della Ricerca Scientifica 1, 00133 Roma, Italy; E-mail:emiliano.trucchi@uniroma2.it

M. Pitzalis \& M. A. Bologna, Dipartimento di Biologia, Università degli Studi Roma Tre, Viale Marconi 446, 00146 Roma, Italy

M. Zapparoli, Dipartimento di Protezione delle Piante, Università della Tuscia, Via San Camillo de Lellis, 00100 Viterbo, Italy

Received 9 January 2009, accepted 24 March 2009

\section{Introduction}

Wild, human-caused and prescribed fires can be considered as important factors that change and model ecosystem diversity and structure (Neary et al. 1999, Granström 2001, Malmström 2006). Fire effects on ecosystems regard the biotic and the abiotic component of soil and aboveground habitats. Particularly important are the changes brought on soil's physical, chemical and biological functions and processes (Neary et al. 1999). The collection and analysis of data from different ecosystems after fire events is still crucial (Malmström 2006), although the knowledge about the direct and indirect effects of fires is rapidly growing (e.g. Sgardelis et al. 1995, Bond \& van Wilgen 1996, DeBano 2000, Swengel 2001). Here we present ecological data about the effects of different severity fire on centipede communities living in anthropogenic semi-natural Mediterranean habitats.

Fire effects on animal communities, both in natural and anthropogenic areas, have been studied mainly in the Australian mallee and in the Cal- 
ifornian chaparral (Collett 1998, Schwilk \& Keeley 1998), while only few studies have been carried out in the Mediterranean region (Sgardelis et al. 1995, Protti 2001). Soil invertebrates have been deeply investigated in Australian mallee after prescribed fires (e.g. Collett 1998) and in North America and in the Mediterranean after wild and human-caused fires (Sgardelis et al. 1995, Groppali et al. 2001). These studies were mostly carried out at higher taxonomic level (order or family) and provide only coarse-grained ecological information. A synecological characterization of the secondary succession supported by a species-level analysis can give more detailed information on dynamics of these ecological processes.

Among soil invertebrates, centipedes represent a group of soil meso- and macroarthropods, common in forest Mediterranean ecosystems (490 in Europe; Minelli 2006). As generalist predators, they can have strong influence on meso- and macro-invertebrate soil communities (e.g. Albert 1983). Species composition and structure of centipede communities could give useful information in order to characterize seminatural as well as disturbed habitats (e.g., Wytwer 1990, 1995, Zapparoli 1992, Grgič \& Kos 2005). Few data about fire effects on centipedes in Central European and Mediterranean forests are discussed by Saulnier \& Athias-Binche (1986), Serra et al. (1992) and Tajovský (2002). Despite lacking of replication and former control data, investigations after wild and human-caused fire are mandatory and can be considered as natural experiments (Malmström 2006). According to this, after a human-caused fire occurred in a Tyrrhenian coastal area near Rome (Central Italy) a wide scale biodiversity monitoring has been organized (Bologna 2002, Pitzalis et al. 2005, Pinto et al. 2006, Ukmar et al. 2007).

In this paper we describe and discuss composition, structure, re-colonisation process and early phases of the post-fire short-term succession of the centipede community in a forest landscape deeply influenced by human activities. The effects brought by canopy (complete vegetation destruction) and surface (soil litter and undergrowth destruction) fire in these ecosystems were also compared.

\section{Materials and methods}

\subsection{Study area}

The research was carried out in the "Pineta di Castelfusano" Urban Park (part of "Litorale Romano" State Natural Reserve), situated in the middle-southern coastal Latium (Italy), near the urbanized area of Ostia (ca. 10-11 inhabit ants $/ \mathrm{km}^{2}$ ), Roma. This area is characterized by a typical Mediterranean climate, belonging to the xerotheric bioclimatic region (thermo-Mediterranean/meso-Mediterranean subregion; Blasi 1994). As regards the whole area of Castelfusano Park (1,000 ha), ca. 340 ha were damaged by fire on July 4, 2000. Data concerning physical and chemical characteristics of fire were not available.

Pedological analyses revealed two main soil types in this area (Gisotti \& Collamarini 1982). The first type is represented by Late Pleistocenic dunes, presently covered by a mature pine-forest (Pinus pinea), planted since the $18^{\text {th }}$ century, by oak wood (Quercus ilex) and Mediterranean shrubland. The second soil type occurs on ancient dune slacks, and it is represented by fragments of wetland vegetation characterized by Populus alba and Quercus robur association.

As in most research on fire effects on biological communities, this study is necessarily retrospective in nature. Unlike empirical trials of designed studies, treatments cannot be randomly assigned and true controls do not exist. Thus, as in similar studies (e.g. Santalla et al. 2002), we used different unburnt habitats as representative of pre-fire conditions because of the lack of data from the study region before fire.

\subsection{Sampling sites}

The following six sampling sites were selected according to different habitat types and intensity of fire (Fig. 1):

- BP1: 120-150 years old pinewoods (Pinus pinea), some 2 ha, $250 \mathrm{~m}$ away from the adjacent unburnt pinewood UP (see below). This site was highly damaged by canopy fire.

- BP2: 120-150 years old pinewoods (Pinus 


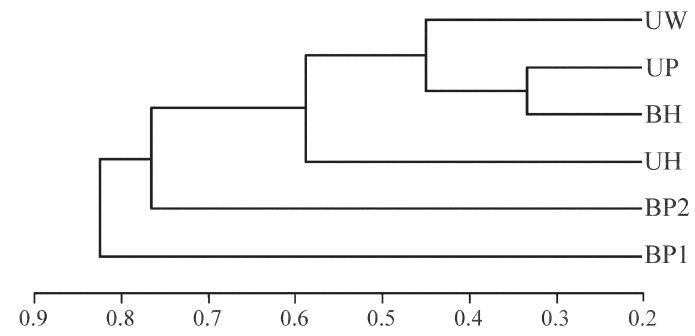

Fig. 1. Cluster analysis (UPGMA method) of six sites obtained by modified values of Jaccard index (for acronyms of sites see text).

pinea), some 2 ha, $50 \mathrm{~m}$ away from the adjacent unburnt pinewood UP (see below). This site was highly damaged by canopy fire

- BH: mixed forest area dominated by holmoak (Quercus ilex), some 1.5 ha, 200-300 m away from UP and about $600 \mathrm{~m}$ away from $\mathrm{UH}$ (see below). This is a low-damaged zone; it was affected by surface fire, which did not destroy tree canopy.

- UP: unburnt 120-150 years old pinewood (Pinus pinea), some 2 ha, adjacent to BP 2 and $\mathrm{BH}$ sites, representing a paraclimax ecosystem; not burnt.

- UH: unburnt holm-oak forest (Quercus ilex), some 2 ha, not burnt.

- UW: unburnt mixed subhygrophilic forest (characterized by age-old Quercus robur specimens and Populus spp.). Although it does not parallel with any burnt habitat, this site represents a very important patch of this landscape (Late Pleistocene dunes and ancient dune slacks) and its biotic communities could play an important role in the recolonization processes of burnt sites.

In addition to being the same forest type (i. e., oak or pine forests), unburnt sites approximately share the elevation, slope, topography, plant association, soil types, and past management practices with the corresponding burnt sites (Blasi et al. 2002).

\subsection{Field sampling}

Monthly samplings were performed from April 2001 to April 2002. Owing to the epigeic and edaphic habits of different species, centipedes were collected with two methods in each site, to obtain a representative sample of both component of the community (e.g. Wytwer 1990, 1995).

(a) Pitfall traps $(500 \mathrm{ml})$ filled with vinegar and formaldehyde were used. Despite concerns about various biases inherent to pitfall traps method (Spence \& Niemelä 1994), it remains the most appropriate sampling methodology for soil arthropods (Ausden 1996). Six pitfall traps, $10 \mathrm{~m}$ spaced, were disposed along a transect in each sampling site. The contents of the 6 traps of each site were collected each month and pooled to reduce single trap sample bias. This material was regarded as representative of the epigean component of taxocoenoses.

(b) Active search was monthly carried out by two of the authors (MP and ET), searching under stones, litter or logs for a standard 1 hour period. These specimens represent the whole community, including both edaphic and epigean species.

Specimens were stored in alcohol $70 \%$ at the Università Roma Tre (Zoological Museum), and partially in the M. Zapparoli collection(Università della Tuscia, Viterbo). Nomenclature and classification follow Minelli (2006). Data on habitat preferences refer to populations from Central Italy (Zapparoli 2006).

\subsection{Data analysis}

Analysis of centipede communities was based on standard methods usually employed in soil zoology (Wytwer 1990, 1995, Magurran 2004).

The pitfall trap sampling method gives no direct indication on density of species, but allows an evaluation of its "activity" in the ecosystem. Data from this sampling method were standardized for quantitative analyses. In particular, activity density $(\mathrm{ADj})$ was calculated for each species as follow: i) monthly $\mathrm{AD}$ (ADjm) of a species was calculated as the average number of specimens captured per trap in a standard 30 days sampling period $(A D j m=n / t \times d / 30$; where $n$ represents the number of captured specimens, $t$ the number of traps used, $d$ the number of days of ex- 
Table 1. Number of centipede specimens caught by direct sampling (first line for each species) and annual activity density of species caught by piffall traps (second line for each species) in three burnt and three unburnt sites (for acronyms of sites see text).

\begin{tabular}{|c|c|c|c|c|c|c|}
\hline & UW & $\mathrm{UH}$ & UP & $\mathrm{BH}$ & BP2 & BP1 \\
\hline $\begin{array}{l}\text { Eupolybothrus fasciatus (Newport, 1845) } \\
\text { Lithobius aleator Verhoeff, } 1925\end{array}$ & $\begin{array}{l}11 \\
2.89 \\
11\end{array}$ & $\begin{array}{l}6 \\
2.91\end{array}$ & $\begin{array}{l}4 \\
1.91 \\
1\end{array}$ & $\begin{array}{l}4 \\
1.45\end{array}$ & 0.16 & \\
\hline Lithobius cassinensis Verhoeff, 1925 & 0.14 & 1 & 264 & 1 & & \\
\hline Lithobius castaneus Newport, 1844 & $\begin{array}{l}2 \\
2.85\end{array}$ & $\begin{array}{l}1 \\
1.90\end{array}$ & 0.53 & $\begin{array}{l}1 \\
0.20\end{array}$ & & \\
\hline Lithobius forficatus (Linnaeus, 1758) & $\begin{array}{l}3 \\
0.20\end{array}$ & & 5 & $\begin{array}{l}7 \\
0.16\end{array}$ & 4 & \\
\hline Lithobius lapidicola Meinert, 1872 & 4 & & 1 & & & \\
\hline Lithobius romanus Meinert, 1872 & & & & & & 1 \\
\hline Lithobius sp.* & & & & & & \\
\hline Scolopendra cingulata Latreille, 1829 & & & 1 & & & \\
\hline Cryptops hortensis (Donovan, 1810) & 4 & & 3 & & 1 & 1 \\
\hline Cryptops parisi Brölemann, 1920 & & & 1 & & & \\
\hline Cryptops trisulcatus Brölemann, 1920 & & & 1 & 1 & & \\
\hline Himantarium gabrielis (Linnaeus, 1758) & $\begin{array}{l}1 \\
0.16\end{array}$ & & 1 & 2 & & 0.17 \\
\hline Stigmatogaster gracilis (Meinert, 1870) & & 11 & 2 & 2 & & $\begin{array}{l}2 \\
0.18\end{array}$ \\
\hline Henia vesuviana (Newport, 1845) & $\begin{array}{l}5 \\
0.16\end{array}$ & 1 & 1 & 3 & & \\
\hline Clinopodes flavidus C. L. Kock, 1846 & 1 & 3 & & & & \\
\hline Geophilus carpophagus Leach, 1815 & $\begin{array}{l}1 \\
0.19\end{array}$ & & 9 & 1 & 1 & \\
\hline Stenotenia sorrentina (Attems, 1903) & & $\begin{array}{l}5 \\
0.17\end{array}$ & 1 & 1 & & \\
\hline Stenotenia romana (Silvestri, 1896) & & 3 & & & & 2 \\
\hline Total & $\begin{array}{l}43 \\
6.59\end{array}$ & $\begin{array}{l}31 \\
5.17\end{array}$ & $\begin{array}{l}31 \\
5.08\end{array}$ & $\begin{array}{l}23 \\
2.50\end{array}$ & $\begin{array}{l}6 \\
0.35\end{array}$ & $\begin{array}{l}6 \\
0.35\end{array}$ \\
\hline
\end{tabular}

* Unrecognizable damaged specimen not referable to any species in the list.

posure of the traps); ii) annual AD of a given species (ADjy) was obtained by adding up monthly ADjm values; iii) total AD of the coenosis (ADy) was obtained summing up the ADjy of the sampled species. This standardized data were used in all subsequent analyses.

Standard statistical indexes were used to characterize the centipede community of each site.
Each species was assigned to a frequency class, which defines the species bond to the studied communities ( $\mathrm{Fj}>50 \%$ : constant species; $\mathrm{Fj}=$ 25-50\%: accessory species; $\mathrm{Fj}=10-25 \%$ : accidental species; $\mathrm{Fj}<10 \%$ : sporadic species; Fallaci et al. 1994). Fj is the frequency of the $\mathrm{j}-\mathrm{th}$ species, calculated as follows: $\mathrm{Fj}=\mathrm{nmj} / \mathrm{NM} \times$ 100 , where: $n m j$ is the number of months when $j-$ 
th species appears and NM is the number of total months of sampling). The assignment of species to dominance classes was used to describe the structure of the community: $\mathrm{Dj}>50 \%$ : eudominant species; $\mathrm{Dj}=10-50 \%$ : dominant species; $\mathrm{Dj}$ $=5-10 \%$ : influent species; $\mathrm{Dj}=2-5 \%$ : recedent species; $\mathrm{Dj}<2 \%$ : subrecedent species. $\mathrm{Dj}$ is the dominance of the $\mathrm{j}-\mathrm{th}$ species and it is calculated as follows: $\mathrm{Dj}=n \mathrm{nj} / \mathrm{N} \times 100$ where $\mathrm{nj}$ is the number of specimens of the $\mathrm{j}$-th species and $\mathrm{N}$ is the total number of specimens. Shannon and Pielou indexes were calculated to evaluate the diversity and the evenness of each community.

The communities under investigation were compared using similarity and correlation indexes. The Jaccard index and the Morisita index were used to estimate the differences among communities as concerns the species composition and the dominance structures, respectively. The values of these indexes were converted in distance matrixes and a cluster average linkage analysis (using the UPGMA method) was performed using MVSP 3.12d (Kavach Computing Services 1985-2001).

Non-parametric statistics, as Spearman correlation coefficient and Kruskal-Wallis ANOVA, were employed to analyze the trend of the recolonization and the succession processes analyzing the monthly progress of abundance and diversity with STATISTICA 5.5 (Stasoft Inc.). The sequential Bonferroni correction (Rice 1989) was used to adjust $\mathrm{p}$-values according to the number of comparisons using the same dataset.

\section{Results}

\subsection{Species composition}

Nineteen species (248 specimens) were collected (Table 1). This value is comparable to that found in neighbouring areas (Zapparoli 1992, 2006).

Differences between burnt sites BP1 and BP2 (with 5 species each) and unburnt sites are greatly marked. On the other hand, burnt site BH hosts 10 species, comparable to those found in the unburnt sites (UH: 8, UP: 15, UW: 10 species respectively).

Lithobius castaneus, L. cassinensis and Henia vesuviana, typical species of woody habitats,

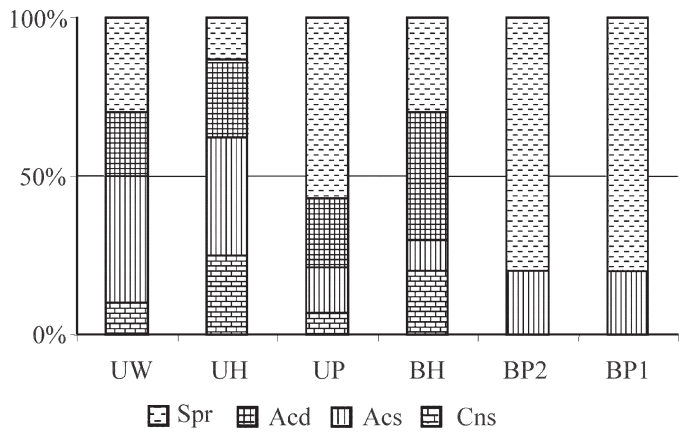

Fig. 2. Assignement of Chilopoda species in frequency classes (Spr = Sporadic; Acd = Accidental; Acs = Accessory; Cns = Constant) at six sites (for acronyms of sites see text).

were not sampled in BP1 and BP2. Conversely, Himantarium gabrielis, Stigmatogaster gracilis, Geophilus carpophagus, Stenotaenia sorrentina, and $S$. romana, five geophilomorphs mostly related to thermophilic Quercus spp. woods, were collected at least in one of the burnt pinewood sites. Eupolybothrus fasciatus and L. forficatus, two medium-large sized and vagile lithobiomorph species were recorded in BP2 only.

Jaccard index points out low similarity values (0.08-0.27) of BP1 and BP2 in comparison with other sites and each other. A main cluster (over $50 \%$ of similarity) including $\mathrm{BH}, \mathrm{UP}, \mathrm{UW}$ resulted from UPGMA analysis (Fig. 1).

The assignment of species to frequency classes (Fig. 2) highlights: (a) a high percentage of sporadic species in BP1 and BP2; (b) a high percentage of constant and accessory species in $\mathrm{UH}$ and UW; (c) a high percentage of sporadic and accidental species in $\mathrm{BH}$ and in UP.

\subsection{Dominance structure}

\subsubsection{Pitfall traps samplings}

Activity densities (Table 1) are higher in unburnt sites (UH, UP, UW) compared to burnt ones (BH, $\mathrm{BP} 1, \mathrm{BP} 2)$. The highest value of Morisita index results in the comparison between UH and UW (0.97), while UP differs from other unburnt sites and shows the highest value in comparison with $\mathrm{BH}$ (0.87). $\mathrm{BH}$ has high values in comparison with other unburnt sites UH (0.83) and UW 
Table 2. Diversity indexes of centipedes by direct sampling (ds) and pitfall traps (pt) in burnt and unburnt sites (for acronyms of sites see text). H'max: In(S); H': Shannon index; J': Pielou index.

\begin{tabular}{|c|c|c|c|c|c|c|c|c|c|c|c|c|}
\hline & \multicolumn{2}{|c|}{ UW } & \multicolumn{2}{|c|}{$\mathrm{UH}$} & \multicolumn{2}{|c|}{ UP } & \multicolumn{2}{|c|}{$\mathrm{BH}$} & \multicolumn{2}{|c|}{ BP2 } & \multicolumn{2}{|c|}{ BP1 } \\
\hline & ds & pt & ds & pt & ds & pt & ds & pt & ds & pt & ds & pt \\
\hline H'max & 2.303 & 1.946 & 2.079 & 1.386 & 2.708 & 1.099 & 2.303 & 1.386 & 1.609 & 0.693 & 1.609 & 0.693 \\
\hline $\mathrm{H}^{\prime}$ & 1.980 & 1.194 & 1.764 & 0.924 & 2.207 & 0.944 & 2.038 & 1.048 & 0.868 & 0.690 & 1.330 & 0.693 \\
\hline J' & 0.860 & 0.614 & 0.846 & 0.667 & 0.816 & 0.859 & 0.885 & 0.756 & 0.541 & 0.995 & 0.826 & 0.999 \\
\hline
\end{tabular}

(0.74). The dendrogram obtained by Morisita index (Fig. 3a) includes one cluster with two groups (UH-UW and BH-UP). Species dominance classes are shown in Fig. 4. Monthly abundance of species supports a significant correlation between UW and UH, between UW and UP and between UP and BH (Spearman correlation, valid $N$ $=12$; UW vs. UH: $r=0.674, p=0.016$, UW vs. UP: $r_{s}=0.802, p=0.0002$; tests were significant also after Bonferroni correction). Other comparisons are non-significant.

\subsubsection{Direct samplings}

The unburnt sites UH, UP, UW host higher number of specimens compared to burnt ones, par-

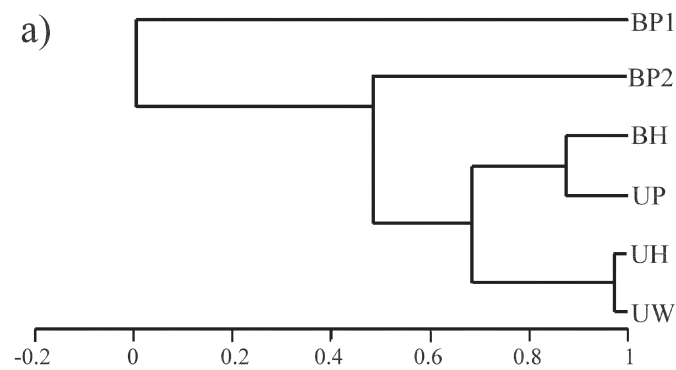

b)

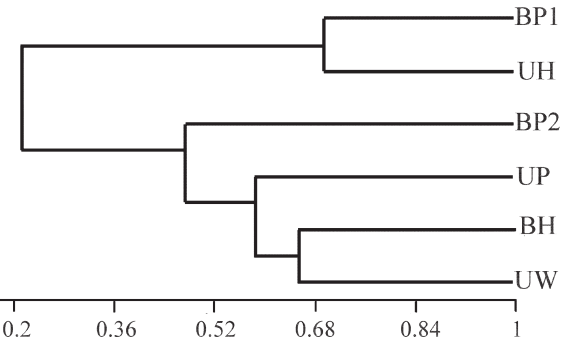

Fig. 3. Cluster analysis (UPGMA method) of six sites obtained by modified values of Morisita index. - a. pitfall traps. - b. direct sampling. For acronyms of sites see text. ticularly in comparison with BP1 and BP2 (Table 1). The highest value of Morisita index results in the comparison between UH and BP1 (0.80) and the lowest one between UH and BP2 (0.00). The dendrogram obtained by Morisita index (Fig. 3b) includes two clusters: the first includes BP1 and $\mathrm{UH}$, the second includes BP2, UP, BH and UW. Species dominance classes are shown in Fig. 4. Monthly abundance of species supports a significant correlation between UH and UP (Spearman correlation, $N=12$; UH vs. UP: $r_{s}=0.798, p=$ 0.002 ; this value resists to Bonferroni correction).

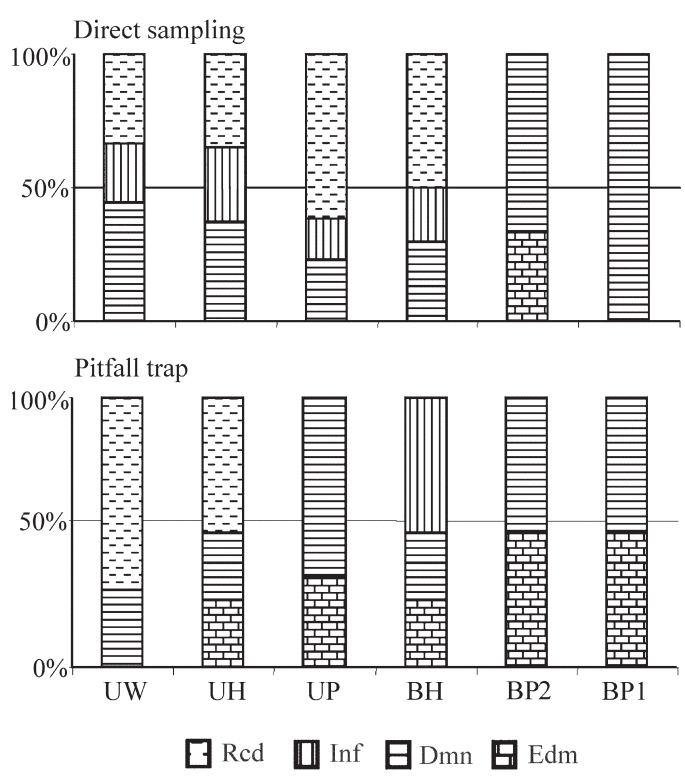

Fig. 4. Assignement of Chilopoda species in dominance classes (Rcd = Recedent; Inf = Influent; Dmn = Dominant; Edm = Eudominant) at six sites (for acronyms of sites see text) in direct sampling and pitfall traps. 


\subsection{Diversity}

Annual diversity indexes of both epigeic and edaphic component of the community are reported in Table 2. The low diversity in BP1 and BP2 is always clear, while medium-high diversity values are observed in $\mathrm{BH}$. In the unburnt sites the lowest value was recorded in UH. Evenness index values are summarized in Table 2. KruskalWallis ANOVA, comparing the monthly trend of species diversity among sites, does not show significant differences $(p>0.05)$ for either $H^{\prime}$ or $J^{\prime}$ as concerns unburnt sites and $\mathrm{BH}$, while $\mathrm{BP} 1$ and $\mathrm{BP} 2$ greatly differ $(p<0.01)$.

\section{Discussion}

\subsection{Unburnt sites}

The centipede communities of the mixed subhygrophilic (UW), holm-oak (UH) and pinewood (UP) forests, show diversity, evenness, patterns of species frequency and dominance comparable to those found in other forest ecosystems in Italian anthropized areas (Minelli \& Iovane 1987, Zapparoli 1992, 2004, 2006). However some differences among sites should be highlighted. Patterns of frequency classes in UW and UH communities are more structured than in UP, in which occasional species (sporadic and accidental) reach $70 \%$. It evidences the dynamic situation of this forest ecosystem, where the growing holm-oak forest is progressively replacing pinewood forest (Blasi et al. 2002). The epigeic component of the centipede community, detected by means of pitfall trapping, shows higher value of annual activity density in UW, probably because of subhygrophilic character of this site (Zapparoli 2004). Though total activity density is similar in UP and in UH, their species assemblage denotes a reshaping of dominance structure. Concerning active searching results, assignment of species to classes of dominance (Fig. 4) confirms the presence of well-structured communities with different dominant species in all unburnt sites. UP hosts the highest number of species (15), probably because of the dynamic condition of this site (above mentioned; Blasi et al. 2002). UH forest community has the lowest number of species (8), confirming the simplified ecological condition of this site, ecosystem probably related to human impact and past forest management activities (coppicing and wood charcoal production). In this ecosystem, a guild of woodland species, including G. osquidatum, a geophilomorph species sampled only in this site, is present. Even if UW represents a distinct subhygrophilic forest, its centipede community is very similar to those of near UP and $\mathrm{BH}$ forests.

\subsection{Fire effects on centipede communities}

Centipede communities, living in sites damaged by canopy fire, clearly show a reduction in number of species and deep modification as regards community structure. Conversely, surface fire seems to not have noticeably affected the community composition. This agrees with other studies about the response to fire of boreal forest insect groups (Malmström 2006). Centipede communities of sites affected by canopy fire are characterized by a loss of species with forest habitat preferences. As detected in other fire-tolerant soil arthropods species (Sgardelis et al. 1995, Pitzalis et al. 2005), low-mobile geophilomorphs probably survived fire, avoiding flames and high temperatures thanks to their aestivation habits in deep soil layers (Lewis 1981, Saulnier \& Athias-Binche 1986). On the other hand, more vagile species with a broad ecological tolerance can also be present as a result of dispersion events from surrounding unburnt areas.

Frequency classes analysis points out a low complexity in the communities of BP1 and BP2. They are both characterized by a high percentage of sporadic species, low values of activity density and low number of specimens. Probably microclimatic changes, due to the loss of tree coverage and to the increased solar radiation, strongly affected centipede communities (Scott \& van Wyk 1990, DeBano 2000). In these two sites, small populations of some species probably survive in the early phases of ecological succession, without establishing structured communities. Annual and monthly diversity indexes, obtained by both sampling methods, strengthen our inferences about the poorer conditions of these burnt pinewood sites. Values of $\mathrm{H}^{\prime}$ in BP1, and J' in BP1 and 
BP2, obtained by direct samplings, are probably biased by the scarce number of specimens recorded in these sites.

Centipede community of the site affected by surface fire $(\mathrm{BH})$ is at the interface between unburnt sites and those affected by canopy fire. Owing to the non-destructive effects of the fire, this site hosts a community with a structured pattern of dominance classes. The annual activity density recorded in $\mathrm{BH}$ - intermediate between UP and BP1/BP2 (Table 1) - may suggest that population sizes of different species has been reduced directly by fire (Certini 2005). Dominance of Lithobius forficatus in both BH and BP2 (not recorded in BP1) is related to the great ability of this species to colonize disturbed habitats (Minelli \& Iovane 1987, Zapparoli 2006). Dominance structure (Fig. 4) and diversity values confirm the presence of well-structured communities in $\mathrm{BH}$ as well as in the unburnt sites. Probably fire did not destroy the whole centipede community by direct incineration and the persistence of the trees canopy has preserved microclimatic conditions suitable to centipede species (Swengel 2001, Arnan et al. 2006).

Low Jaccard similarity values of the two burnt pinewood sites in comparison with unburnt ones, point out that deep structural changes of centipede community occurred after fire. Moreover, BP1 and BP2 have only one species in common (Cryptops hortensis). Conversely, $\mathrm{BH}$ is closely related with UP, UW and UH sites (Fig. 1). Considering also the values of Morisita index calculated on pitfall trap samplings, the burnt holm-oak site has medium-high values in all comparisons with all the unburnt ones. This result highlights that few changes in the dominance structure were caused by fire.

\section{Conclusions}

Although centipedes are generic predators with a wide spectrum of habitat and trophic preferences (Lewis 1981, Minelli \& Iovane 1987, Voigtländer 2005, Zapparoli 2006), they mainly inhabit forest ecosystems. As many other epigeic arthropods, their survival, in general and after fire, mostly depends on microclimatic conditions, such as soil moisture (Daas et al. 1995). In Mediterranean habitats, different fire severity produces distinct effects on centipede communities as evidenced by our analysis on species composition, dominance structure, and diversity indexes. Communities affected by a surface fire were scarcely modified and do not substantially differ from the unburnt sites. On the other hand, communities affected by canopy fire suffered greater changes in diversity, abundance and structure as discussed in literature (Buddle et al. 2006, Malmström 2006).

Two kinds of fire effects (Malmström 2006) can affect Mediterranean centipede communities. (a) Immediate damages (direct effects - heat and hazardous gases) may have a lower impact on centipedes, as they can escape under soil surface. Moreover, if fire occurs during the Mediterranean summer, centipedes result less damaged because they usually migrate in the deeper soil layers in order to find suitable wet conditions (Sgardelis et al. 1995). (b) Fire also causes microclimatic changes lasting for a long time (York 2004), such as more xeric conditions due to the complete destruction of the tree coverage (indirect effects post-fire drought and starvation). This effect strongly involves centipedes as well as other soil invertebrates. Moreover, reduced prey density could be regarded to as another long-term effect of fire (Sgardelis et al. 1995, Pitzalis et al. 2005).

Acknowledgements. The research was supported by grants from the Rome Municipality (Dipartimento X) ("Studio delle dinamiche successionali post-incendio nell'area di Castelfusano e valutazione dell'effetto dei lavori di ripristino sulla ricolonizzazione animale" project, coordinator M. A. Bologna).

\section{References}

Albert, A. M. 1983: Characteristics of two populations of Lithobiidae (Chilopoda) determined in the laboratory and their relevance with regard to their ecological role as predators. - Zoologischer Anzeiger 211: 214-226.

Arnan, X., Rodrigo, A. \& Retana, J. 2006: Post-fire recovery of Mediterranean ground ant communities follows vegetation and dryness gradient. - Journal of Biogeography 33: 1246-1258.

Ausden, M. 1996: Invertebrates. — In: Sutherland, W. J. (ed.), Ecological census techniques: a handbook. Cambridge University Press, Cambridge. 336 pp.

Blasi, C. 1994: Fitoclimatologia del Lazio. — Fitosociologia 27: 151-175.

Blasi, C., Cignini, B., Dellisanti, R. M. \& Montagna, P. 
2002: Il recupero ambientale della pineta di Castel Fusano, studi e monitoraggi. — Palombi, Roma. 48 pp.

Bologna M. A. 2002: La fauna di Castelfusano. Studio delle dinamiche successionali post-incendio. Valutazione dell'effetto dei lavori di ripristino sulla ricolonizzazione animale. — In: Blasi, C., Cignini, B., Dellisanti, R. M. \& Montagna, P. (eds.), Il recupero ambientale della pineta di Castel Fusano, studi e monitoraggi. Palombi, Roma. 48 pp.

Bond, W. J. \& van Wilgen, B. W. 1996: Fire and plants. Population and community biology series 14 . - Chapman and Hall, London. 263 pp.

Buddle, C. M., Langor, D. W., Pohl, G. R. \& Spence, J. R. 2006: Arthropod responses to harvesting and wildfire: Implications for emulation of natural disturbances in forest management. - Biological Conservation 128: 346-357.

Certini, G. 2005: Effects of fire on properties of forest soils: a review. - Oecologia 143: 1-10.

Collett, N. G. 1998: Effects of two short rotation prescribed fires in autumn on surface-active arthropods in dry sclerophyll eucalipt forest of west-central Victoria. Forest Ecology and Management 107: 253-273.

Daas, T., Bouzerna, N. \& Descamps, M. 1995: Influence des facteurs écologiques sur la répartition des chilopodes dans l'est algérien. —-Bulletin de la Société Zoologique de France 120: 21-27.

DeBano, L. F. 2000: The role of fire and soil heating on water repellency in wildland environments: a review. Journal of Hydrology 231-232: 195-206.

Fallaci, M., Colombini, I. \& Chelazzi, L., 1994: An analysis of the Coleoptera living along a Tyrrhenian beachdune system: abundances, zonation and ecological indices. - Vie Milieu 44: 243-256.

Gisotti, G. \& Collamarini, D. 1982: Suolo e vegetazione nella Tenuta di Castelporziano. - Genio rurale 45: $35-56$.

Granström, A. 2001: Fire management for biodiversity in the European boreal forest. - Scandinavian Journal of Forest Research 3: 62-69.

Grgič, T. \& Kos, I. 2005: Centipede diversity in differently structured forests in Slovenia. - Peckinana 4: 49-56.

Groppali, R., Marinone, M. \& Pesarini, C. 2001: Appunti sui Ragni di Celle Ligure e Varazze (Provincia di Savona): importanza della distanza dalla costa e ricolonizzazione di ambienti incendiati (Arachnida, Araneae). - Atti della Società italiana di Scienze naturali, Museo civico di Storia naturale di Milano 142: 227 241.

Lewis, J. G. E. 1981: The Biology of Centipedes. - Cambridge University Press, Cambridge. 476 pp.

Magurran, A. E. 2004: Measuring biological diversity. Blackwell publishing, Oxford, UK. 256 pp.

Malmström, A. 2006: Effects of Wildfire and Prescribed Burning on Soil Fauna in Boreal Coniferous Forests. - PhD. thesis. Swedish University of Agricultural Sciences. Acta Universitatis Agriculturae Sueciae, Uppsala. 111 pp.

Minelli, A. 2006: A World Catalogue of Centipedes (Chilopoda). — [www document]. URL http://chilobase- biounipdit/docs/chilobasephp. (Site visited on 10 January, 2009)

Minelli, A. \& Iovane, E. 1987: Habitat Preferences and Taxocenoses of Italian Centipedes. - Bollettino del Museo Civico di Storia Naturale di Venezia 37: 7-34.

Neary, D. G., Klopatek, C. C., DeBano, L. F. \& Folliot, P. F. 1999: Fire effects on belowground sustainability: a review and synthesis. - Forest Ecology and Management 122: 51-71.

Pinto, F., Bombi, P. \& Bologna, M. A. 2006: Effects of fire and forest restoration on two sympatric species of Lacertidae (Reptilia) in a Mediterranean ecosystem of Central Italy. — Revue d'Ecologie: La Terre et la Vie 61: 195-200.

Pitzalis, M., Fattorini, S., Trucchi, E. \& Bologna, M. A. 2005: Comparative analysis of species diversity of Isopoda Oniscidea and Collembola communities in burnt and control habitats in Central Italy. - Italian Journal of Zoology 72: 127-140.

Protti, M. 2001: Uccelli e incendi: indagini preliminari. Avocetta 25: 120.

Rice, W. R. 1989: Analyzing tables of statistical tests. Evolution 43: 223-225.

Santalla, S., Salgado, J. M., Calvo, L. \& Fernandez, M. 2002: Changes in Carabidae community after a large fire in a Pinus pinaster stand. - In: Trabaud, L. \& Prodon, R. (eds.), Fire and biological processes. Backhuys, Leiden. 345 pp.

Saulnier, L. \& Athias-Binche, F. 1986: Modalités de la cicatrisation des écosystème méditerranéens aprés incendie: cas de certains arthropodes du sol 2. Les myriapodes édaphiques. — Vie Milieu, 36: 191-204.

Schwilk, D. W. \& Keeley, J. E. 1998: Effects of wildfire on rodent populations. - Southwest Naturalist 43: 480 483.

Scott, D. F. \& van Wyk, D. B. 1990: The effects of wildfire on soil wettability and hydrological behaviour of an afforested catchment. - Journal of Hydrology 121: 239-256.

Serra, A., Mateos, E., Parra, X. \& Sarlé, V. 1992: Estudio de los efectos de un incendio forestal sobre poblaciones de artrópodos edáficos. - Historia Animalium 1: 41-62.

Sgardelis, S. P., Pantis, J. D., Argyropoulou, M. D. \& Stamou, G. P. 1995: Effects of fire on soil macroinvertebrates in a Mediterranean Phryganic ecosystem. International Journal of Wildland Fire 5: 113-121.

Spence, J. R. \& Niemelä, J. K. 1994: Sampling carabid assemblages with pitfall traps: the madness and the method. - The Canadian Entomologist 126: 881894.

Swengel, A. B. 2001: A literature review of insect responses to fire, compared to other conservation managements of open habitat. - Biodiversity and Conservation 10: 1141-1169.

Tajovský, K. 2002: Soil macrofauna (Diplopoda, Chilopoda, Oniscidea) in a pine forest disturbed by wild fire. — In: Tajovský, K, Balik, V. \& Pižl, V. (eds.), Studies on soil fauna in Central Europe. Proceedings of the 6th 
Central European Workshop on Soil Zoology, České Budějovice, Czech Republic, April 23-25, 2001.

Ukmar, E., Battisti, C., Luiselli, L. \& Bologna, M. A. 2007 : The effects of fire on communities, guilds and species of breeding birds in burnt and control pinewoods in central Italy. - Biodiversity and Conservation 16: 3287-3300.

Voigtländer, K. 2005: Habitat preferences of selected Central European centipedes. - Peckiana 4: 163-179.

Wytwer, J. 1990: Chilopoda of linden-oak-hornbeam (Tilio-Carpinetum) and thermophilous oak forests (Potentillo albae-Quercetum) of the Mazovian Lowland. — Fragmenta faunistica 34: 73-94.

Wytwer, J. 1995: Faunistical relationship between Chilopoda of forest and urban habitats in Mazowia. - Fragmenta faunistica 38: 87-133.

York, A. 2004: Long-term effects of frequent low-intensity burning on the abundance of litter-dwelling invertebrates in coastal Blackbutt Forests of south-eastern Australian. - Journal of Insect Conservation 3: 191199.
Zapparoli, M. 1992: Preliminary data on centipede communities of Querceta ilicis and Fagetalia sylvaticae in Central Italy. - Berichte des NaturwissenschaftlichMedizinischen Vereines in Innsbruck, suppl 10: 197204.

Zapparoli M., 2004: Structure and diversity of the centipede taxocoenoses (Chilopoda). — In: Cerretti, P., Hardersen, S., Mason, F., Nardi, G., Tisato, M. \& Zapparoli, M. (eds.), Invertebrati di una foresta della Pianura Padana, Bosco della Fontana. Secondo contributo. Centro Nazionale per lo Studio della Biodiversità Forestale Bosco della Fontana; Corpo Forestale dello Stato; Ministero dell'Ambiente e Tutela del Territorio, Servizio Conservazione Natura. Cierre Editore. 304 pp.

Zapparoli, M. 2006: A catalogue of the centipedes (Chilopoda) of Central Apennines (Italy). — Bollettino del Museo civico di Storia naturale di Verona, Botanica, Zoologia 30: 165-273. 